\title{
Gaya hidup konsumtif dan pencitraan diri mahasiswa pengguna Instagram (Studi kasus pada mahasiswa kelas menengah di Kabupaten Jember)
}

\author{
Adillia Risky Cahyaningtyas*, Muhammad Iqbal \\ Universitas Negeri Malang, Jl. Semarang No. 5 Malang, Jawa Timur, Indonesia \\ *Penulis korespondensi, Surel: adliarisky@gmail.com
}

Paper received: 2-1-2021; revised: 23-1-2021; accepted: 30-1-2021

\begin{abstract}
Abstrak
Penelitian ini bertujuan untuk menganalisis dan mendeskripsikan fenomena gaya hidup pencitraan di media sosial instagram berdasarkan studi kasus pada mahasiswa kelas menengah yang ada di kabupaten Jember. Penelitian ini menggunakan metode kualitatif dengan jenis deskriptif. Subjek pada penelitian ini yaitu mahasiswa kelas menengah. Informan pada penelitian ini yaitu mahasiswa kelas menengah yang tersebar di beberapa kampus yang ada di kabupaten Jember dan aktif sebagai selebgram atau endorsement produk pada media sosial instagram. Teknik pengumpulan data yang digunakan dalam penelitian ini yaitu wawancara mendalam, observasi partisipasi, dan dokumentasi. Teknik analisis data yang digunakan adalah mengumpulkan data, reduksi data, penyajian data, dan penarikan kesimpulan. Hasil penelitian menunjukkan bahwa mahasiswa kelas menengah di kabupaten Jember mencitrakan diri melalui empat hal antara lain pemilihan fashion dengan tujuan untuk menirukan tokoh yang dijadikan sebagai role model, kemudian aktivitas foodstagramming (makan cantik) dan juga kongkow di restoran atau cafe bergengsi untuk menunjukkan bahwa mereka adalah mahasiswa yang memiliki selera tinggi dalam mengonsumsi makanan, selanjutnya melalui gaya hidup kaum milenial dalam perspektif cybermedia yang ditandai dengan berbagai macam pencitraan dalam bentuk unggahan foto maupun video di media sosial instagram, terakhir yaitu budaya konsumtif bagi kaum milenial yang menerangkan bahwa mayoritas mahasiswa yang melakukan pencitraan yaitu mereka yang berasal dari kelas sosial menengah dengan jatah uang saku lebih dari cukup setiap bulannya, sehingga mereka cenderung berperilaku konsumtif.
\end{abstract}

Kata kunci: Cybermedia; Milenial; Role of Model; Instagram

\section{Pendahuluan}

Globalisasi yang dialami oleh masyarakat saat ini dianggap memberikan dampak perubahan pada segala aspek kehidupan. Hal yang tak luput dari adanya globalisasi adalah kemajuan teknologi dan komunikasi. Saat ini teknologi yang sedang berkembang dapat menyebabkan perubahan sosial dan ekonomi dalam masyarakat. Adanya kemajuan teknologi dan komunikasi dapat berdampak pada seseorang, yang awalnya mereka hanya membutuhkan kebutuhan yang bersifat jasmani (sandang, pangan, dan papan) namun dengan berkembangnya teknologi tersebut kebutuhan seseorang akan bertambah pula seperti kebutuhan akan eksistensi diri (pengakuan). Kebutuhan akan eksistensi diri ini merupakan bagian dari perubahan gaya hidup seseorang.

Gaya hidup merupakan cara seseorang menampilkan dirinya di hadapan umum. Gaya hidup merupakan ciri sebuah dunia modern atau modernisasi. Artinya, siapa pun yang hidup dalam masyarakat modern akan menggunakan gagasan tentang gaya hidup untuk menggambarkan tindakannya sendiri maupun orang lain. Gaya hidup selalu berkaitan dengan upaya membuat diri eksis dengan cara tertentu dan berbeda dari kelompok lain. Seseorang cenderung ingin menampilkan citra dirinya untuk mendapatkan pengakuan dari orang lain dan 
sebagai upaya meningkatkan eksistensi diri. Gaya hidup dapat dijadikan sebagai acuan untuk menampilkan identitas diri melalui penggunaan waktu, uang, dan barang. Untuk melihat gaya hidup seseorang dapat dilihat dari barang - barang yang dimiliki dan dipakai sehari - hari yang biasanya bersifat modis dan trendy. Kondisi ini hampir melanda semua lapisan dan generasi masyarakat, salah satunya mahasiswa.

Fenomena dari mahasiswa saat ini tercermin dari cara berpakaian dan berpenampilan yang terkadang berlebihan dalam memilih gaya untuk dirinya sendiri. Seharusnya mahasiswa merupakan golongan muda yang mengisi waktunya dengan menambah pengetahuan, keterampilan, serta mengisi kegiatan mereka dengan hal - hal positif sehingga memiliki orientasi sebagai manusia yang bermanfaat di masa yang akan datang. Akan tetapi saat ini pergaulan dengan teman telah menjadikan mahasiswa yang menyandang predikat sebagai kaum intelektual dan mengabdikan dirinya untuk belajar bergeser menjadi ingin mendapatkan pengakuan dari orang lain. Fenomena seperti ini juga terjadi pada mahasiswa kelas menengah di Kabupaten Jember.

Sebagai salah satu wilayah dengan beberapa universitas baik negeri maupun swasta, kabupaten Jember menjadi salah satu daerah yang memiliki populasi masyarakat dengan usia remaja yang cukup banyak, dan sebagian besar dari populasi remaja tersebut adalah kaum mahasiswa. Jember juga termasuk dalam kategori kota besar ke 3 di Jawa Timur yang sedang berkembang menjadi kota metropolitan. Hal ini dibuktikan dengan gaya hidup yang berlebihan dan serba kekinian seperti gaya berpakaian, berdandan, berfoto, dan sebagainya yang dilakukan oleh para mahasiswa melalui media sosial.

Kemajuan teknologi dan komunikasi ditandai dengan munculnya media sosial yang dapat digunakan bagi para pengguna yang ingin berkomunikasi jarak jauh namun secara real time. Kehadiran media sosial di kalangan anak muda menjadikan ruang privat individu berubah menjadi ruang publik sehingga hal ini memicu terjadinya pergeseran budaya di kalangan anak muda (Ayun, 2015). Media sosial menawarkan berbagai kemudahan berkomunikasi yang dapat digunakan oleh semua orang untuk berinteraksi atau sekedar mencari hiburan melalui dunia maya.

Media sosial merupakan suatu produk terbaru dari adanya kemajuan teknologi komunikasi. Media sosial terlahir setelah adanya internet dan mulai meluas secara global. Theory of cyber media memperkenalkan istilah "cyberspace" untuk menjelaskan bahwa ada tempat di mana ia tidak nyata tetapi keberadaannya dapat dirasakan bahkan menjadi kenyataan dalam benak. Itulah yang disebut ruang siber yaitu nyata di benak individu seolah komentar yang dilakukan antar pengguna media sosial merupakan percakapan yang dilakukan sehari - hari, sehingga siapapun dapat merasa bahagia atau sedih ketika membacanya (Nasrullah, 2016). Media sosial bisa menjadi ruang untuk melakukan interaksi satu sama lain dimana para penggunanya bisa dengan mudah berpartisipasi, berbagi, dan menciptakan isi di dalamnya, misalnya melalui aplikasi Facebook, Twitter, You Tube, Instagram, Google Plus, Path, WA, Line, dan E - mail. Survei yang dilakukan oleh Asosiasi Penyelenggara Internet Indonesia (2017) menyatakan bahwa media sosial yang menduduki peringkat teratas paling banyak diakses adalah Instagram.

Instagram sendiri muncul pada 6 Oktober 2010 dan dengan berjalannya waktu Instagram menjadi media sosial yang menduduki peringkat teratas paling banyak diminati oleh generasi muda utamanya para mahasiswa. Instagram pertama kali ditemukan oleh Kevin 
Systrom dan Mike Krieger. Instagram merupakan aplikasi yang memungkinkan penggunanya untuk berbagi foto dan video dalam waktu yang cepat. Instagram sendiri memiliki fitur - fitur yang menarik seperti mengedit, memberi caption dan membagikannya kepada pengguna instagram lain. Selain itu melalui instagram foto maupun video yang diunggah bisa langsung dibagikan pada jejaring sosial lainnya seperti facebook, twitter, dan tumblr. Instagram tidak hanya dimanfaatkan untuk berbagi informasi, tapi juga sebagai ajang ekspresi diri dan pencitraan yang memungkinkan seseorang untuk memposting foto dan video di suatu tempat yang terkenal dan mewah, sehingga dari situ akan membentuk citra diri yang akan menghasilkan identitas bagi pelaku pencitraan tersebut. Proses pembentukan citra diri melalui Instagram ditunjukkan dengan semakin banyak angka followers (pengikut) dan like (menyukai) di berbagai postingan foto ataupun video si pemilik akun instagram. Jika si pengguna sudah memenuhi kriteria dengan jumlah followers dan like yang banyak, maka dapat dikatakan bahwa si pengguna dapat menjadi figur bagi remaja masa kini karena dianggap memiliki citra diri yang tinggi (Febriana, 2016).

Pencitraan diri merupakan cara seseorang membentuk kesan atau gambaran mengenai dirinya. Citra diri akan terbentuk jika seseorang menunjukkan penampilan yang menarik hingga membuat orang lain terkesan dan menyukai penampilannya. citra diri (self image) adalah bagaimana persepsi orang lain terhadap seseorang. Citra diri akan terbentuk jika seseorang menunjukkan gaya hidup atau penampilan yang menarik hingga membuat orang lain terkesan atau menyukai gaya hidup dan penampilannya (Fitria, 2015). Citra diri (self image) yang diartikan persepsi orang lain terhadap seseorang yaitu ketika citra diri melahirkan suatu gaya atau perilaku tertentu, terutama perilaku yang berkaitan dengan bagaimana ia membentuk image atau kesan di mata orang lain. Pada dasarnya seseorang membangun sebuah citra dirinya dimaksudkan untuk mendapatkan perhatian ataupun penghargaan dari orang lain, untuk itu seseorang memperbanyak simbol - simbol pada dirinya. Simbol - simbol tersebut bisa berupa produk - produk modernitas. Persepsi orang lain terhadap seseorang tersebut juga bisa ditunjukkan dengan gaya berpakaian (fashion) dimana pada saat ini para mahasiswa sering menirukan fashion dari artis ataupun selebgram yang menjadi idolanya. Sosok idola yang biasa dijadikan acuan dalam hal fashion disebut role model. Hal ini sejalan dengan teori mimesis yang dicetuskan oleh Rene Girard, dimana untuk mendapatkan kesan yang diharapkan seseorang akan berusaha meniru gaya atau fashion orang lain yang dianggapnya sebagai role model.

Konsep Girardian tentang mimesis tidak ingin mengubah kualitas antara model dengan tiruan, karena setiap orang pasti meniru. Perilaku manusia didasarkan pada sebuah ekspresi yang mencakup segala imitasi. Kualitas yang diinginkan oleh model juga telah dikembangkan melalui imitasi. Peran sebagai model adalah akibat dari mimesis dan tidak dapat dianggap sebagai sesuatu yang istimewa, atau dianggap lebih substansial daripada sebuah tiruan. Originalitas tergantung pada mimesis, yaitu terletak pada kemampuan untuk menemukan makna dalam aspek yang berbeda dari konfigurasi-konfigurasi mimetik dan menempatkan unsur-unsur mimetik secara bersama-sama dalam sebuah gaya (fashion) yang original dan fundamental. Kemampuan ini tidak berasal dari anggapan yang sesungguhnya tetapi muncul dari imitasi yang khusus, sejenis percampuran mimetik yang pelik, sehingga tidak dapat dipungkiri bahwa kita hidup dari mimesis, setiap orang pasti pernah ber-mimesis dan setiap orang ada kemungkinan untuk di-mimesis (Cahyaningtyas, 2019). 
Selain melalui penampilan (fashion) mayoritas mahasiswa kelas menengah di kabupaten Jember juga mencitrakan diri melalui barang - barang branded yang dimiliki, aktivitas kongkow dan foodstagramming (makan cantik) yang biasa dilakukan di restoran atau cafe berkelas, maupun travelling ke berbagai tempat wisata baik yang ada di dalam kota maupun di luar kota. Hal tersebut dilakukan untuk menunjukkan kepada khalayak bahwa mereka berasal dari status sosial menengah bahkan keatas. Menurut Bourdieu gaya hidup seseorang dipahami sebagai hasil dari interaksi antara manusia sebagai subjek sekaligus objek dalam masyarakat, hasil dari pemikiran sadar dan tak sadar yang terbentuk sepanjang sejarah hidupnya. Bourdieu pun menyatakan gaya hidup merupakan sebuah rangkaian atau proses sosial panjang yang melibatkan modal, kondisi objektif, habitus, disposisi, praktik, gaya hidup, struktur selera, dan sistem tanda. Hal tersebut menuntut individu supaya memiliki modal - modal khusus untuk dapat hidup secara baik dan bertahan di dalamnya. Modal - modal yang dimiliki akan menunjukkan eksistensi seseorang dalam masyarakat, misal status sebagai pecinta kuliner mampu menciptakan suatu prestise tertentu bagi seseorang, sedangkan jenis makanan yang dikonsumsi beserta restoran yang disinggahi dijadikan sebagai tanda (sign) yang menjadi simbol bahwa seseorang tersebut berasal dari kelas sosial menengah (Bourdieu dalam Cahyaningtyas, 2019) sehingga dapat disimpulkan bahwa seseorang yang mampu melakukan pencitraan di instagram yaitu mereka yang berasal dari status sosial menengah bahkan keatas, karena untuk memenuhi berbagai keinginan tersebut diperlukan biaya tinggi, dan para mahasiswa yang mampu mencapainya adalah mereka yang uang saku per bulannya lebih dari cukup yaitu kisaran 1,5 juta keatas.

Berdasarkan uraian diatas dapat diketahui bahwa gaya hidup pencitraan pada mahasiswa kelas menengah di kabupaten Jember terdapat suatu hal yang menarik untuk diteliti, oleh karena itu peneliti mengambil judul penelitian "Gaya Hidup Konsumtif dan Pencitraan Diri Mahasiswa Pengguna Instagram (Studi Kasus pada Mahasiswa Kelas Menengah di Kabupaten Jember)."

\section{Metode}

Penelitian ini dilakukan di beberapa perguruan tinggi yang berlokasi di Kabupaten Jember, Jawa Timur. Jenis penelitian yang digunakan yaitu deskriptif dengan pendekatan kualitatif. Peneliti menggunakan jenis ini untuk menghasilkan informasi dan mendeskripsikan fenomena yang akan diamati. Sumber data dalam penelitian ini ada dua yaitu, informan inti dan juga informan tambahan. Jenis data yang digunakan yaitu data primer dan data sekunder. Penelitian ini menggunakan tiga metode dalam pengumpulan data yaitu, metode wawancara mendalam, metode observasi partisipasi dan metode dokumentasi. Perolehan data dilakukan dengan beberapa tahap atau disebut juga triangulasi (triangulation). Tahap selanjutnya yaitu analisis data, dimana sebuah penelitian akan dikumpulkan menjadi satu kemudian dianalisis untuk dideskripsikan agar sesuai dengan fokus permasalahan yang akan diteliti. Analisis data menggunakan model (Miles, Huberman, \& Saldana, 2014) yang terdiri dari tiga tahapan yaitu kondensasi data, penyajian data dan penarikan kesimpulan.

\section{Hasil dan Pembahasan}

\subsection{Hasil}

Berdasarkan penelitian yang dilakukan, peneliti telah mendapatkan hasil yang sesuai dengan tujuan penelitian ini yaitu mengetahui Gaya Hidup Konsumtif dan Pencitraan Diri 
Mahasiswa Pengguna Instagram Studi Kasus pada Mahasiswa Kelas Menengah di Kabupaten Jember.

\subsubsection{Fashion Sebagai Role of Model}

Fashion kini menjadi salah satu hal yang penting bagi kaum remaja salah satunya mahasiswa kelas menengah di kabupaten Jember. Berikut ungkapan BA tentang arti fashion bagi dirinya:

"fashion adalah bagaimana cara memadupadankan pakaian untuk mencapai gaya atau style yang cocok. Setiap orang pasti memiliki selera fashion masing - masing yang cocok dengan postur tubuh maupun kepribadian mereka, serta yang menurut mereka nyaman dipakai." (BA, 19 tahun)

Perkembangan fashion dikalangan mahasiswa juga tidak terlepas dari pengaruh media. Media kini telah menjadi makanan sehari - hari bagi kaum remaja utamanya mahasiswa, karena media menawarkan berbagai kemudahan dalam mengakses segala sesuatu salah satunya berbagai model fashion terkini. Sebelum memutuskan untuk membangun citra diri, seseorang akan mencari jati dirinya terlebih dahulu. BA, DN, KJ, dan NF mengungkapkan bahwa mereka memiliki role model untuk fashion mereka. BA memilih selebgram asal Bandung Rili Herdalda sebagai role of model nya, DN memilih selebgram cantik Nanda Arsynta atau jika dari kalangan artis dia mengidolakan Chika Jessica dengan alasan karena kedua selebriti yang diidolakan tersebut memiliki kesamaan postur dengan dirinya yang kecil dan mungil, KJ dan NF memilih artis korea sebagai sosok yang mereka idolakan yaitu para personil girl band blackpink, sedangkan PS menyatakan bahwa dirinya lebih suka mix and match gaya busana yang ia suka, namun PS juga mengaku bahwa sedikit banyak ia meniru fashion artis - artis hollywood favoritnya seperti Selena Gomez, berbeda pendapat dengan RF dia mengaku lebih memilih style fashion nya sendiri tanpa meniru orang lain.

Hasil peniruan atau mimesis dari segi penampilan tersebut biasanya ditampilkan dalam bentuk foto ataupun video oleh para mahasiswa yang diunggah di berbagai media sosial baik itu facebook, path, instagram, whatsapp, dan lain - lain, namun diantara berbagai media sosial tersebut yang paling banyak digunakan di kalangan mahasiswa kelas menengah di kabupaten Jember yaitu instagram. Hal ini karena menurut mereka instagram lebih mewakili status sosial menengah dibandingkan media sosial yang lain, karena dalam aplikasi tersebut banyak menampilkan fashion dan gaya berbusana yang up to date, sehingga dapat disimpulkan bahwa sebagian besar dari pengguna instagram adalah seseorang yang berasal dari kelas sosial menengah bahkan keatas.

\subsubsection{Budaya Foodstragaming dan kongkow pada Kelas Sosial Menengah}

Pada saat ini para mahasiswa cenderung menyukai berbagai aktivitas yang mengarah pada kesenangan, mereka biasa melakukan foodstagramming atau makan cantik di suatu restoran berkelas. Seperti halnya yang diungkapkan oleh RF :

"Kalau di restoran berkelas seperti pizza hut, plate - o, solaria, conatto atau mungkin glovic bakery, aku hobi banget foto atau video makanannya, terus nanti diunggah di highlight instagram, kalau makan cantik fokus utama yang aku tampilkan tentu makanannya, cuma terkadang juga ada foto selfie ku waktu makan atau mungkin foto desain interior restoran tempat aku makan." (RF, 22 tahun) 
Foodstagramming atau makan cantik biasanya dilakukan di restoran - restoran kelas menengah atau foodcourt yang terdapat di mall - mall besar seperti lippo plaza ataupun transmart. Berbagai aspek menjadi pertimbangan masyarakat dalam memilih restoran antara lain dekorasi atau desain interior ruangan, penyajian makanan, cita rasa makanan, dan klasifikasi restoran tersebut dalam pandangan masyarakat, apakah restoran tersebut mewakili kalangan sosial menengah atau tidak.

Tahap berikutnya setelah pemilihan tempat, masuk pada kegiatan inti yaitu makan cantik. Sesampainya di restoran para pelaku makan cantik memesan makanan seperti para pengunjung lainnya, namun setelah makanan yang dipesan datang mereka tidak langsung menyantap makanan tersebut, melainkan memotret makanan dari berbagai sisi terlebih dahulu. Mereka memotret makanan tersebut berkali - kali sampai mendapatkan hasil foto yang cantik dan mempesona dari segi tampilan dan terlihat lezat dari segi rasa, sehingga membuat orang lain tertarik untuk mengunjungi restoran tersebut.

Terakhir yaitu kegiatan inti dari makan cantik dimana pelaku memberitahukan kegiatan makannya di media sosial yang mereka miliki. Media sosial yang biasa dimanfaatkan untuk mengunggah foto ataupun video ketika sedang melakukan makan cantik yaitu instagram. Itulah mengapa aktivitas ini pada akhirnya disebut foodstragamming atau aktivitas makan di suatu restoran yang diunggah dan dipublish melalui instagram (Destriana, 2019)

Foodstragaming memiliki beberapa kesamaan dengan apa yang disebut kongkow. Jika dalam foodstragaming lebih berfokus pada aktivitas makan yang dilakukan di restoran, kongkow lebih berfokus pada aktivitas berkumpul yang biasa dilakukan di cafe - cafe terkenal seperti Excelso, Grand Cafe, CTRL + A, dan lain - lain, karena selain mengutamakan cita rasa kopi yang disajikan, cafe - cafe tersebut juga memberikan sentuhan emosi yang mendukung terbentuknya gengsi sosial serta citra diri bagi para penikmatnya. Hal ini sejalan dengan ungkapan PS salah seorang informan yang memiliki hobi kongkow di cafe - cafe hits yang ada di wilayah Jember.

"Aku selalu penasaran kalau ada cafe baru di Jember bawaannya pengen nyoba, tapi yang paling jadi favoritku sih tetep excelso, karena kalau ngopi disana aku selalu mendapat pengalaman ngopi yang luar biasa baik dari menu maupun interior cafenya yang high class. Gak heran kalau disana terkenal sebagai tempat kongkow nya mahasiswa hits." (PS, 21tahun)

Aktifitas seperti halnya foodstragaming dan kongkow yang dilakukan di restoran maupun cafe berkelas sering diabadikan dalam bentuk foto oleh para pelakunya. Melalui foto mereka dapat menyebarluaskan aktivitasnya di media sosial, dan dengan cara tersebut mereka di lingkungan pergaulannya. 


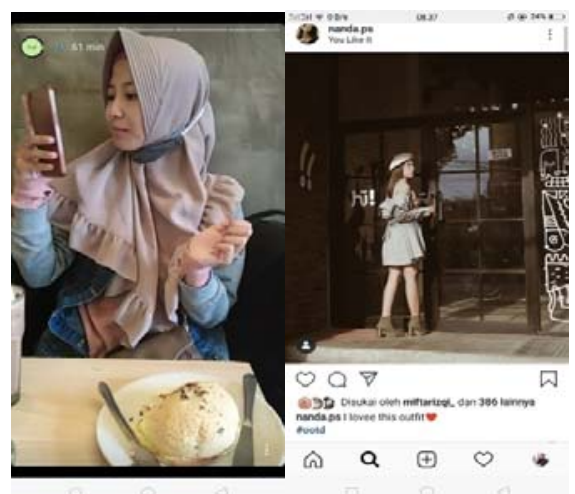

\section{Gambar 1. Kegiatan Foodstagraming dan kongkow pada Kelas Sosial Menengah (Sumber :} Informan RF \& PS)

\subsubsection{Gaya Hidup Milenial dalam Perspektif Cybermedia}

Gaya hidup dalam perspektif cybermedia lebih mengarah pada segala sesuatu yang berkaitan dengan pencitraan diri dikalangan mahasiswa utamanya yang dilakukan melalui media sosial. Berbagai kecanggihan yang ditawarkan oleh media sosial ternyata tidak hanya berdampak positif namun juga berdampak negatif, salah satunya hal tersebut menjadikan mahasiswa berlomba - lomba untuk menunjukkan eksistensi diri dengan cara mengeksplore kecantikan, kepemilikan barang - barang tertentu, prestasi, hobi, dan segala sesuatu yang mereka anggap perlu diketahui orang lain demi menunjukkan citra terbaiknya di hadapan publik. Seperti halnya yang diungkapkan oleh PS, salah seorang informan yang senang mengkonsumsi barang - barang branded untuk menunjang pembentukan citra diri, baik di kehidupan sehari - hari maupun di dunia maya :

"Aku orangnya suka banget ngoleksi sepatu dan yang paling aku favoritin yaitu sepatu boots. Kenapa aku suka, karena menurutku keren aja dan bikin gayaku terlihat makin elegant, aku sampai nabung buat beli sepatu boots merk zara biar makin terlihat berkelas." (PS, 21 tahun)

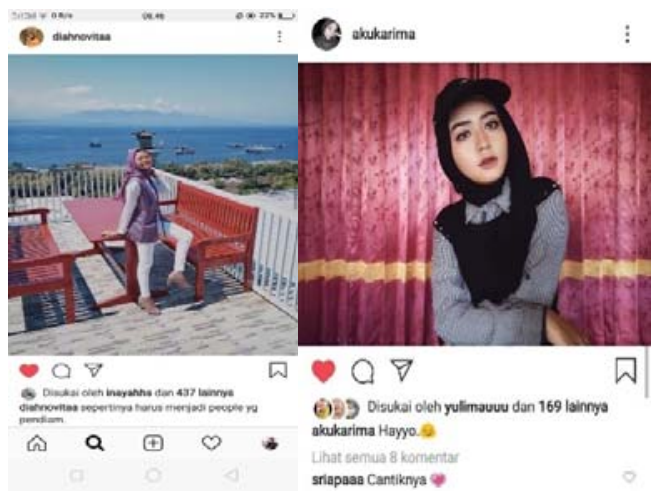

Gambar 2. Gaya Hidup Kaum Milenial dalam Perspektif Cybermedia (Sumber : Informan DN \& KJ) 
Seluruh informan mencitrakan diri melalui kelebihan yang dimiliki seperti kecantikan, prestasi, maupun barang - barang branded. Informan PS misalnya, ia mencitrakan diri melalui barang branded yaitu dengan memakai sepatu merk zara. Hal tersebut tentu menjadikan prestise dan citra diri PS meningkat baik di dunia maya maupun nyata, karena salah satu tujuan dari pemakaian barang branded yaitu mendefinisikan diri sebagai mahasiswa yang bergaya hidup fashionable dan berasal dari keluarga berada. KJ dan BA lebih mencitrakan diri melalui kecantikan dan bakat yang dimiliki khususnya KJ karena ia memiliki bakat ngedance, menyanyi, dan bermake up sedangkan BA ia hanya memiliki bakat bermake up dan fotografi saja. NF dan RF lebih menunjukkan kesan sebagai mahasiswa yang senang hangout ke mall dan berwisata kuliner di berbagai cafe dan restoran. Hal tersebut menunjukkan bahwa mereka memiliki selera tinggi dalam mengonsumsi makanan. Terakhir yaitu DN yang lebih menampilkan kesan sebagai seorang mahasiswa yang hobi melakukan travelling serta mengeksplore berbagai tempat wisata. Hasil wawancara yang dilakukan dengan enam informan inti pun menyatakan bahwa mereka biasa mengedit foto terlebih dahulu, dengan menyematkan filter untuk menambahkan kesan aesthetic sebelum membagikannya pada media sosial instagram.

\subsubsection{Gaya Hidup Konsumtif bagi Kaum Milenial}

Gaya hidup konsumtif dilakukan untuk mencitrakan diri sebagai seseorang yang layak dikagumi oleh orang lain di sekelilingnya, dan untuk mencapai keinginan tersebut setiap orang perlu memiliki modal materi yang lebih dari cukup. Sebagian besar mahasiswa mendapatkan jatah uang saku dari orang tua, entah itu bulanan atau mingguan. Setiap informan mendapatkan uang saku dari orang tua kurang lebih 1,5 - 3 juta perbulan, dari jatah tersebut persentase untuk mengkonsumsi suatu barang berbeda - beda pula antar informan.

Berikut tabel yang menunjukkan tingkat konsumtifitas informan berdasarkan alokasi uang bulanan yang diberikan oleh orang tua:

Tabel 1. Alokasi Uang Bulanan Informan

\begin{tabular}{|c|c|c|c|c|c|c|}
\hline No & Nama & Uang Bulanan & Makan & Belanja & $\begin{array}{l}\text { Kongkow/ } \\
\text { traveling }\end{array}$ & $\begin{array}{c}\text { Kebutuha } \\
\text { n Kuliah }\end{array}$ \\
\hline 1 & $\mathrm{BA}$ & Rp 2.500.000 & $\begin{array}{c}\text { Rp } 1.650 .000 \\
(66 \%)\end{array}$ & $\begin{array}{c}\text { Rp 600.000 } \\
(24 \%)\end{array}$ & $\begin{array}{c}\text { Rp } 200.000 \\
(8 \%)\end{array}$ & $\begin{array}{c}\text { Rp } 50.000 \\
(2 \%)\end{array}$ \\
\hline 2 & DN & Rp 3.000.000 & $\begin{array}{c}\text { Rp } 1.600 .000 \\
(53,3 \%)\end{array}$ & $\begin{array}{c}\text { Rp } 600.000 \\
(20 \%)\end{array}$ & $\begin{array}{c}\text { Rp 700.000 } \\
(23,3 \%)\end{array}$ & $\begin{array}{c}\text { Rp } 60.000 \\
(2 \%)\end{array}$ \\
\hline 3 & $\mathrm{KJ}$ & Rp 2.300.000 & $\begin{array}{c}\text { Rp } 1.500 .00 \\
(65,2 \%)\end{array}$ & $\begin{array}{c}\text { Rp } 550.000 \\
(24 \%)\end{array}$ & $\begin{array}{c}\text { Rp } 175.000 \\
(7,6 \%)\end{array}$ & $\begin{array}{c}\text { Rp } 70.000 \\
(3 \%)\end{array}$ \\
\hline 4 & PS & Rp. 3.000 .000 & $\begin{array}{c}\operatorname{Rp} 1.600 .000 \\
(53,3 \%)\end{array}$ & $\begin{array}{c}\text { Rp } 675.000 \\
(22,5 \%)\end{array}$ & $\begin{array}{l}650.000 \\
(21,6 \%)\end{array}$ & $\begin{array}{l}50.000 \\
(1,6 \%)\end{array}$ \\
\hline 5 & $\mathrm{NF}$ & Rp. 1.500 .000 & $\begin{array}{c}\text { Rp } 900.000 \\
(60 \%)\end{array}$ & $\begin{array}{c}\text { Rp 350.000 } \\
(23,3 \%)\end{array}$ & $\begin{array}{l}175.000 \\
(11,6 \%)\end{array}$ & $\begin{array}{c}\text { Rp } 75.000 \\
(5 \%)\end{array}$ \\
\hline 6 & $\mathrm{RF}$ & Rp. 2.000 .000 & $\begin{array}{c}\text { Rp } 1.200 .000 \\
(60 \%)\end{array}$ & $\begin{array}{c}\text { Rp } 300.000 \\
(15 \%)\end{array}$ & $\begin{array}{c}\text { Rp 450.000 } \\
(22,5 \%)\end{array}$ & $\begin{array}{c}\text { Rp 50.000 } \\
(2,5 \%)\end{array}$ \\
\hline
\end{tabular}

Sumber : Data diolah pada tahun 2019

BA seorang mahasiswa dari Universitas Muhammadiyah Jember (Jurusan Manajemen Fakultas Ekonomi dan Bisnis) dengan jatah bulanan sebesar Rp 2.500.000 mengalokasikan uang sakunya yang pertama untuk konsumsi makanan sebesar $66 \%$, kemudian untuk jatah uang belanja $24 \%$, uang kongkow atau travelling $8 \%$, dan yang terakhir kebutuhan kuliah yang 
hanya berpresentase $2 \%$ dari seluruh uang bulanan BA yang menunjukkan bahwa BA lebih banyak mengalokasikan uang sakunya untuk makan - makan serta belanja.

DN mahasiswa Politeknik Negeri Jember Program Studi Gizi Klinik dengan jatah bulanan Rp 3.000.000 per bulan mengalokasikan uangnya untuk memenuhi kebutuhan makan sebesar 53,3\%, memenuhi kebutuhan belanja 20\%, memenuhi kebutuhan kongkow atau travelling $22,3 \%$, dan kebutuhan kuliah $2 \%$. Hal ini sesuai dengan foto - foto yang diunggahnya di instagram dimana DN lebih mengekspresikan dirinya sebagai mahasiswi modern yang senang mengeksplore tempat wisata.

KJ mahasiswi Jurusan Kebidanan pada Polkesma Cabang Jember dengan jatah bulanan Rp 2.300.000 per bulan mengalokasikan uangnya untuk memenuhi kebutuhan makan sebesar $65,2 \%$, memenuhi kebutuhan belanja 24\%, memenuhi kebutuhan kongkow atau travelling $7,6 \%$, dan kebutuhan kuliah 3\%. Hal ini sesuai dengan foto maupun video KJ di akun instagramnya dimana dia lebih mengeksplore bakat - bakat yang dimilikinya seperti menyanyi, ngedance, dan make up.

PS mahasiswi jurusan Ilmu Hukum Universitas Jember dengan jatah bulanan Rp 3.000.000 per bulan mengalokasikan uangnya untuk memenuhi kebutuhan makan sebesar $53,3 \%$, kebutuhan belanja 22,5\%, kebutuhan kongkow atau travelling 21,6\%, dan kebutuhan kuliah 1,6\%. Hal ini tidak mengherankan karena ketika melihat foto - foto PS di akun instagramnya sudah terlihat bahwa dirinya adalah mahasiswa paling hits di kalangan Fakultas Keguruan dan Ilmu Pendidikan.

NF dari Fakultas Ekonomi Institut Agama Islam Negeri (IAIN) Jember dengan jatah bulanan Rp 1.500.000 per bulan mengalokasikan uangnya untuk memenuhi kebutuhan makan sebesar $60 \%$, kebutuhan belanja 23,3\%, kebutuhan kongkow atau travelling 11,6\%, dan kebutuhan kuliah 5\%. Hal ini terlihat dari postingan pada akun instagram NF dimana ia lebih menonjolkan citra dirinya sebagai seorang pecinta kuliner sehingga anggaran uang jajannya mencapai $60 \%$ adalah untuk membeli makanan.

Terakhir yaitu RF dari Program Studi Ilmu Keperawatan STIKES Dr. Soebandi Jember dengan jatah uang saku Rp 2.000.000 per bulan mengalokasikan uangnya untuk memenuhi kebutuhan makan sebesar $60 \%$, kebutuhan belanja 15\%, kebutuhan kongkow atau travelling $22,5 \%$, dan kebutuhan kuliah 2,5. RF adalah salah seorang informan yang mencintai kuliner sehingga dia mengalokasikan uang makannya sebesar $60 \%$. Hal ini dibuktikan dengan sorotan pada insta story pada akun instagram RF dimana ia sering mengunggah foto - foto foodstragamingnya di restoran - restoran menengah seperti halnya solaria, pizza hut, conatto, dan lain - lain.

Melalui data yang disajikan diatas, disimpulkan bahwa pencitraan diri selalu berkaitan erat dengan gaya hidup konsumtif, karena untuk menampilkan kesan terbaik seseorang di mata publik diperlukan biaya tinggi. Oleh karena itu para mahasiswa yang mendapat predikat hits di media sosial instagram sebagian besar yaitu mereka yang berasal dari kelas sosial menengah dengan jatah uang saku lebih dari cukup setiap bulannya. 


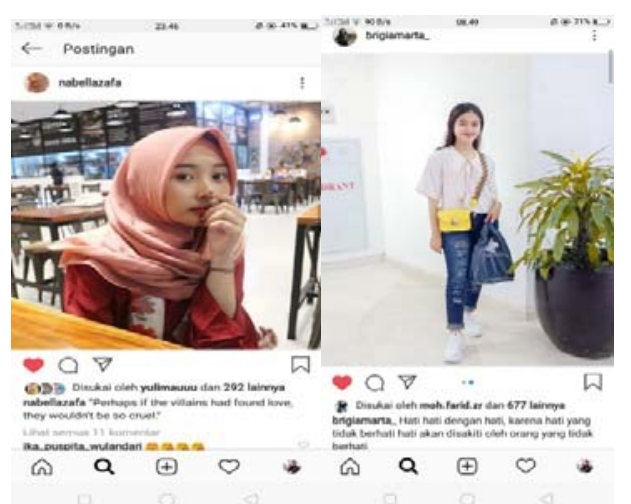

Gambar 3 Gaya Hidup Konsumtif Kaum Milenial

\subsection{Pembahasan}

Fashion pada saat ini telah menjadi tolak ukur masyarakat modern dalam menilai kelas sosial seseorang. Hal ini juga berlaku bagi kalangan mahasiswa, kebanyakan dari mereka memiliki role model dalam urusan berpenampilan. Umumnya yang mereka jadikan role of model yaitu artis maupun selebgram hits. Lima dari enam informan memiliki role of model masing - masing. BA memilih selebgram Rilli Herdalda, DN memilih Nanda Arsynta atau Chika Jessica, KJ dan NF sama - sama memilih artis korea yaitu Jeni dan Lisa Black Pink, PS memilih artis hollywood Selena Gomez, sedangkan RF merasa lebih nyaman berpenampilan sesuai gaya fashionnya sendiri tanpa harus meniru para artis ataupun selebgram. Perilaku dari kelima informan yaitu BA, DN, KJ, NF, serta PS didukung oleh teori mimesis yang dikemukakan oleh Rene Girard yang menyatakan bahwa mimesis atau peniruan adalah suatu upaya untuk mendapatkan kesan yang diharapkan dengan cara menirukan penampilan atau fashion dari seorang yang dijadikan sebagai role model atau sosok yang diidolakan. (Girard dalam Cahyaningtyas, 2019). Selain fashion mahasiswa kelas menengah juga menyukai gaya hidup terkait budaya yang sedang trend pada saat ini yaitu makan cantik atau foostagramming di restoran mewah serta kongkow di cafe berkelas.

Menurut RF dan NF citra yang diharapkan dari pandangan orang lain yaitu seorang mahasiswa yang memiliki selera tinggi terhadap makanan yang dikonsumsi beserta pemilihan tempat makannya misalnya di restoran yang telah memiliki positioning brand tinggi di kalangan mahasiswa seperti Conatto, Solaria, Bvgilgelato, Lengquas Bistro, dan lain - lain. Hal ini sejalan dengan teori yang menyatakan foodstagramming atau makan cantik sebagai ajang pencitraan diri ditunjukkan dengan pemilihan restoran yang dikunjungi dan makanan yang disantap (Fitria, 2015).

Budaya mahasiswa kelas menengah tidak hanya identik dengan foodstragaming atau makan cantik saja namun ada pula yang disebut kongkow. Misalnya PS, ia adalah salah satu mahasiswa yang memiliki hobi kongkow di cafe - cafe mewah, PS pun mengatakan bahwa dirinya lebih menyukai kongkow di cafe daripada makan cantik di restoran, dengan alasan ketika kongkow kesan nongkrong bersama teman - teman menjadi lebih nyata. Hal ini sejalan dengan teori yang menyatakan perkembangan budaya yang diikuti oleh mahasiswa kelas menengah pada saat ini salah satunya adalah dengan mengkonsumsi gaya hidup yang terkesan nyaman serta mempunyai prestise yang tinggi untuk tetap menjaga dan membawa identitas dalam dirinya (Afdholy, 2019). Pola konsumtif ini dapat dilihat dari kebiasaan yang sering 
dilakukan mahasiswa kelas menengah pada saat ini seperti kebiasaan nongkrong di tempat tempat bergengsi, perilaku tersebut dilakukan oleh para mahasiswa kelas menengah untuk mendapatkan pengakuan dan menaikkan citra diri pada lingkungan pergaulannya. Hal tersebutlah yang melatarbelakangi mahasiswa kelas menengah sering mengunjungi coffee shop (Lestari, 2021).

Makanan adalah salah satu yang sangat diperhatikan oleh kalangan menengah, karena dapat dijadikan sebagai strategi konsumsi dengan tujuan untuk membedakan diri dengan kelas sosial lain atau disebut distinction (Bourdue dalam Cahyaningtyas, 2019). Hal ini juga dipengaruhi oleh media sosial yang sangat digandrungi oleh kaum milenial utamanya para mahasiswa. Mahasiswa kelas menengah di kabupaten Jember selalu berusaha menunjukkan kelebihannya ketika show of di instagram seperti kecantikan, prestasi, maupun barang - barang branded. Informan PS misalnya, ia mencitrakan diri melalui barang branded yang dimilikinya yaitu dengan mengenakan sepatu merek zara. Hal tersebut tentu menjadikan prestise dan citra diri PS meningkat baik di dunia maya maupun nyata, karena salah satu tujuan dari pemakaian barang branded yaitu mendefinisikan diri sebagai mahasiswa yang bergaya hidup fashionable dan berasal dari keluarga berada. KJ dan BA lebih mencitrakan diri melalui kecantikan dan bakat yang dimiliki. NF dan RF lebih menunjukkan kesan sebagai mahasiswa yang senang hangout ke mall dan berwisata kuliner di berbagai cafe dan restoran, sedangkan DN lebih menampilkan kesan sebagai seorang mahasiswa yang hobi melakukan travelling serta mengeksplore berbagai tempat wisata.

Gaya hidup milenial yang sarat akan pencitraan diri lahir karena pada saat ini kita telah masuk pada era modern, nilai yang terus berkembang pada saat ini ialah nilai modernitas yang dipengaruhi oleh adanya media siber atau cyber media. Cybermedia adalah suatu hal yang lebih mengarah pada dunia maya. Perkembangan dari adanya cybermedia sendiri yaitu munculnya berbagai media sosial yang saat ini banyak dimanfaatkan oleh kaum milenial dalam memenuhi kebutuhan akan informasi dan komunikasi. Hal ini pada mulanya tidak terlepas dari fungsi cyberspace yaitu menciptakan kontak halus antar individu yang terhubung dalam media sosial sehingga mereka dapat merasakan komunikasi dengan mudah seperti halnya mereka berada dalam ruang dan waktu yang bersamaan (Rulli Nasrullah, 2016).

Jenis media sosial yang sering digunakan remaja pada saat ini khususnya mahasiswa adalah Instagram. Dampak yang ditimbulkan karena maraknya penggunaan instagram bagi mahasiswa yaitu munculnya gaya hidup konsumtif, karena untuk menjadi sosok yang dikagumi tentu seseorang perlu mengeluarkan biaya lebih. Untuk mencitrakan diri sebagai seseorang yang berpenampilan menarik BA dan PS selalu membeli baju - baju dengan model terkini, membeli peralatan make up, dan sebagainya. Berbeda ketika mereka ingin mencitrakan diri sebagai sosok yang mengikuti perkembangan zaman seperti halnya NF dan RF, mereka selalu update tempat - tempat kongkow seperti cafe, mall, ataupun restoran berkelas untuk mengidentifikasikan diri sebagai kaum muda yang bergaya hidup modern, berbeda pula dengan DN sebagai seorang pecinta travelling, ia tentu membutuhkan biaya lebih untuk sekali melakukan perjalanan wisata. Hal inilah yang membuat para pelaku pencitraan cenderung menerapkan gaya hidup konsumtif.

\section{Simpulan}

Berdasarkan hasil dari penelitian yang dilakukan, peneliti menyimpulkan bahwa mayoritas mahasiswa kelas menengah di Jember memiliki prioritas yang berbeda - beda dalam 
mencitrakan dirinya melalui media sosial Instagram. Beberapa diantara mereka mencitrakan diri dengan mengenakan pakaian brand tertentu, beberapa yang lain mencitrakan diri sebagai seseorang yang senang travelling dan mengeksplore alam serta berbagai tempat wisata, ada pula yang mencitrakan diri sebagai seorang pecinta kuliner dan hobi kongkow di cafe. Pencitraan tersebut marak dilakukan mahasiswa melalui media sosial Instagram dalam bentuk foto, video, ataupun story, tujuannya agar mereka menjadi sosok yang tersohor dengan jumlah like dan followers yang tinggi sehingga orang lain menganggapnya sebagai sosok yang diharapkan (wish image). Pencitraan diri yang dilakukan mahasiswa salah satunya bertujuan untuk menirukan tokoh yang dianggapnya sebagai role of model. Tokoh yang umumnya dijadikan sebagai role of model bagi mahasiswa yaitu artis ataupun selebgram (selebrity instagram). Untuk dapat menirukan figur - figur tersebut diperlukan kapital ekonomi yang lebih dari cukup dari latar belakang keluarga yang berprofesi sebagai pengusaha, PNS, Wiraswasta, maupun TNI.

Membangun citra diri memang penting untuk meningkatkan status sosial dimata orang lain, tetapi sebisa mungkin berbijaklah dalam menggunakan media sosial, diperbolehkan bagi para mahasiswa untuk melakukan pencitraan diri selagi itu adalah citra yang mengarah pada hal - hal positif. Janganlah menjadikan media sosial sebagai ajang panjat sosial (social climbing) atau bergaya lebih dari kemampuan (hyperreality). Utamakan skala prioritas dalam mengkonsumsi sesuatu, karena mayoritas para mahasiswa belum mampu berpenghasilan sendiri. Kontrol sosial dari orang tua pun sangat diperlukan supaya anak - anak mereka tidak terjerumus dalam dunia pencitraan yang memicu terjadinya gaya hidup yang konsumtif.

\section{Daftar Rujukan}

Afdholy, N. (2019). Perilaku Konsumsi Masyarakat Urban Pada Produk Kopi Ala Starbucks. Satwika : Kajian Ilmu Budaya Dan Perubahan Sosial, 3(1), 43-53. https://doi.org/10.22219/satwika.v3i1.8681

Ayun, P. Q. (2015). Fenomena Remaja Menggunakan Media Sosial dalam Membentuk Identitas. CHANNEL: Jurnal Komunikasi, 3(2), Article 2. https://doi.org/10.12928/channel.v3i2.3270

Destriana, N. M. (2019). Hiperrealitas Masyarakat Surakarta pada Makanan (Fenomena Makan Cantik dan Foodstagramming Pemuda di Surakarta).

Febriana, M. (2016). Hiperrealitas “Angka” dalam Instagram (Studi Fenomenoogi tentang Dampak Media Sosial dikalangan Peserta Didik SMA Negeri 4 Surakarta). SOSIALITAS; Jurnal Ilmiah Pend. Sos Ant, 5(2)

Fitria, H. (2015). Hiperrealitas dalam Social Media (Studi Kasus: Makan Cantik di Senopati pada Masyarakat Perkotaan). Informasi, 45(2), 87-100. https://doi.org/10.21831/informasi.v45i2.7985

Lestari, L. P. (2021). Konstruksi Identitas Anak Muda Urban Dalam Memanfaatkan Coffee Shop

Cahyaningtyas, A. R. (2019). Gaya Hidup Pencitraan Mahasiswa Pengguna Instagram.

Nasrullah, N. R. (2016). Teori dan Riset Media Siber (cybermedia). Kencana. 